\title{
FROM POLICIES TO LIVED EXPERIENCE AND BACK: THE STRUGGLE FOR REINTEGRATING RETURNEES OF HUMAN TRAFFICKING IN GOIÁS STATE (CENTRAL WEST BRAZIL)
}

\author{
Runa Lazzarino*
}

\begin{abstract}
This article is based on a fieldwork research conducted mainly in the Brazilian state of Goiás, with a focus on the returnees of human trafficking $(\mathrm{HT})$. The text is funnel-shaped: from the international and national policies, to the relevance of Goiás state as a hotspot area for investigating both the phenomenon and the measures to counter it, to the voices of some key governmental and non-governmental operators directly assisting and caring about the needs of the ex-victims, up to the everyday more intimate life of an emblematic case of a social actor. The aim is to let emerge the complexities of the standpoints around the issue of reintegration of the returnees of HT. The return is conceived not only as a mere geographical displacement, as a simple homecoming or as a matter of good protection policies and programmes. It is also approached as a deep, long and tortuous resettlement of the subjectivities undertaking it. Indeed, through the story of Sabrina, I intend to point out the value of good policies, state measures, humanitarian aid services, but also the distance between these last ones and the actual conditions of the psychosocial suffering of the return migrants, their families and communities.
\end{abstract}

Keywords: Human trafficking (returnees); policies; return migration; reintegration; aid services; Goiás (Brazil).

\section{Introduction}

The first time I meet Sabrina ${ }^{1}$ is through her voice filtered by a microphone. Hidden somewhere backstage, inside the Municipal Theatre of

\footnotetext{
* PhD candidate in anthropology at Università degli Studi di Milano-Bicocca. Milan/Italy.

${ }^{1}$ Sabrina is a pseudonym, as well as the names of her family members and friends.
} 
Anápolis, she is giving testimony of her experience as a returned ex-victim ${ }^{2}$ of human trafficking (HT) during the Regional Seminar on the Fight against Trafficking in Persons held in June $2012^{3}$. The voice of Sabrina synthetically retraces her story, when her sister, her cousin and herself were offered and enticed by a trafficker, in their brothel outside Anápolis, to go to Spain to continue their job as sex workers, yet with far higher incomes. She talks about the tricks used to make them trust and foretaste the promised luxurious conditions of their future employment and life-style in Europe: they bought them clothes, took them to the beauty salon, did not show fear in front of the police in the airports, made them proper passports near the town hall, and so on. She mentions how, once in Spain, she soon noticed the actual indignity of the new job conditions and felt deeply humiliated: severely restricted in her freedom, with a growing debt and unbearable working hours. "I knew it was for prostitution, but I did not imagine all that" ${ }^{\prime 4}$.

Then, she suddenly stops recalling that sad situation and starts talking instead about how her life completely changed thanks to the organization Projeto Resgate [Project Rescue] ${ }^{5}$, which helped her to come back home. The way Sabrina depicts her return is in terms of a radical modification and bettering of her life. After going through numerous and unimaginable difficulties, she managed to come back, she definitely abandoned prostitution, she can pay for her house, and she is now "the owner of her own business, thanks God". And she also underlines "[...] The work of Projeto Resgate is a real work, because you don't imagine what human trafficking is, you don't

\footnotetext{
2 It is only for ease of reading that I don't put the word "victim" between inverted commas, while I am aware of the debate around the use of the term in human trafficking and migration studies (see, for example, AGUSTÍN, Laura María. Forget Victimization: granting agency to migrants; ANDRIJASEVIC, Rutvica. Beautiful Dead Bodies: Gender, Migration and Representation in AntiTrafficking Campaign; DOEZEMA, Jo. Who Gets to Choose? Coercion, Consent and UN Trafficking Protocol; O'CONNEL, Davidson J. New Slavery, Old binaries: human trafficking and the borders of "freedom"). Nonetheless, even without using it unproblematically, the focus of the article lays elsewhere.

3 The seminar was promoted by the Centre to Counter Trafficking in Persons (from now NETP) in Goiás, the Secretary of Policies for Women and Promotion of Racial Equality (from now on Semira) and the Government of Goiás, all around the main urban centres of the state as part of the awareness raising and prevention activities. In Anápolis, the event was organized by the Directorship of Public Policies for Women and the Reference Centre for Women of the Municipal Secretary of Social Development. I use the initials of the Brazilian name to respect the original acronym. Therefore, NETP stays for Núcleo de Enfrentamento aoTráfico de Pessoas, which I translated as Centre to Counter Trafficking in Persons. I keep the old name, even if in Goiás the NETP changed name into Executive Commission last year. Semira stays for Secretária de Políticas para Mulheres e Promoção da Igualdade Racial [Secretary of Policies for Women and Promotion of Racial Equality].

4 Recorded speech, 25/6/2012, Anápolis (GO). All the quotations and extracts from the interviews and other material in Brazilian Portuguese are translated into English by myself.

5 Projeto Resgate (PR) will be introduced later in this text.
} 
imagine that traffickers are here, really here [...] pimps are inside the bus station, here in the town hall square, close to the Federal Police office".

When listening to that tormented faceless voice on that occasion, I could not predict that I was going to know Sabrina very well, up to the point of ending up living in her house, with her two children and her partner. I also did not know that many of the people present at the seminar, including the country representative of Projeto Resgate, the coordinator of the NETP and the psychologist responsible for HT cases in the Reference Centre for Women of Anápolis, were to constitute the most familiar and helpful faces of my fieldwork in Central Brazil.

This article is based on a fieldwork research, conducted from May to October 2012, between the three closed cities of the Brazilian Central Highlands: Brasília, Goiânia and Anápolis. This period of ethnographic investigation is part of a four years transnational doctoral project on HT, with particular focus on the area of protection and assistance to the returnees ex-victims of trafficking ${ }^{6}$. The other contexts of the research have been in Northern Vietnam, specifically Hanoi and Lao Cài cities and surroundings, and Kathmandu and surroundings in Nepal. While I interpret here the ethnographic case drawn from the Brazilian experience, when attempting broader reflections around the processes of returning, I inevitably bring with me a luggage of the extended research in the other contexts and of the study of the socio-anthropological literature on migration of return and HT.

Nonetheless, in this text, I have decided to present a first systematization of the "data" collected on the Brazilian field, trying to avoid interpretative interferences and without charging the description with references to theoretical frameworks and other studies. By giving to the text a bottleneck-like structure, from the international and national policies to the inner world of an emblematic case of a social actor, and by carefully selecting the extracts of the interviews to some of my interlocutors, the aim is to let emerge possible and general deductions around the issue of reintegration. The underlying idea is that long-term and macro processes, traditions and policies, get ultimately inscribed in the micro-localities, lives and bodies

\footnotetext{
6 The key objective of the project was to elaborate further interpretations around the anthropological issues of subjectivity, sense making and self (re)-construction - in contexts of uprootedness, violence and suffering - within the human sciences' debate, providing a qualitative perspective working transnationally with the returned "ex-victims" of trafficking and the policies and services around them. Provocatively aware of addressing an abstract and homogenizing category, the study precisely aspired to be an ethnographic counterpoint of the diverse, thick and interpersonal living experience of the social actors who return to their home countries after having been trafficked, enslaved or exploited abroad.
} 
of the individuals ${ }^{7}$. Furthermore, by showing different perspectives on HT returnees' protection, the aim was also to give a sense of the complex arena of actors, making up HT discourse and practices, and how distant they can be in their language, actions and views.

More specifically, in this article, around the processes of return and needs for reintegration, I will present various points of view: of the Brazilian government in response to the Palermo Protocol; of the NETP in Goiás, with its history and relevance as a hotspot area of HT; of some operators of few organizations of the NETP in Anápolis and Goiânia; and, finally, of Sabrina, a returnee of HT, living in the industrial suburban area of Anápolis. Without aspiring to generalize in a transversal model the figure of the returnee of $\mathrm{HT}$, even if there are some specific traits regarding this particular kind of migrant (in particular the deception and exploitation suffered and the status of victim eligible of aid services), a further objective is to illustrate how the return is a long and tortuous process - lasting even years - which sees the subject suspended in transition between a before and an after: a self-perceived and socially constructed identity before and after, a local world and a set of relationships before and after, a familiar and professional contexts which have also changed ${ }^{8}$. Coming back starts abroad, firstly in the elaboration of the decision, and continues in the country of origin, in order to possibly end when a sense of resettlement and located life planning, more or less peacefully, provides the ex-victim with a renovated sense of belonging to a social milieu, being this the pre-departure one or a new home.

This means that it is hard to talk of "return" home stricto sensu, considering the strong impact of the trafficking and migratory experience on the life of the ex-victim, the changes occurred in the net of relationships with her/his friends, acquaintances, and family members, the modifications of her/his private role in the family and public role in the community and society ${ }^{9}$, and the acquisition of the status of victim of HT. The return is here, of course, conceived not only: as a mere geographical displacement, as a bureaucratic State border crossing and repatriation procedure, as a statistical phenomenon. It is also approached as an active transformation of the subjectivity of the social actors undertaking it. The agency of the returnee of trafficking is particularly striking when we think that it arouses in contrast of

7 ABU-LUGHOD, Lila. Writing against culture, p. 150; BRETTELL, Caroline. Anthropology and Migration. Essays on Transnationalism, Ethnicity, and Identity, p. 23-45.

8 CASEY, Edward S. Getting Back Into Place: Toward a Renewed Understanding of the Place-World, p. 297.

9 MARKOWITZ, Fran. The Home(s) of Homecomings. 
two potentially disempowering positions: the one of "victim of trafficking" and labour exploitation and the one of "failed migrant" often rescued and deported, who lost her/his gambling in the migratory endeavour ${ }^{10}$.

In the next paragraph, I consider the aid services for returnees designed by law, both according to the UN Convention and the Brazilian legislation and policies. Next, I will introduce the NETP within the scenario of the state of Goiás as a hotspot area of trafficked persons, reporting some data and the hypotheses of some activists and experts. In the third paragraph, I illustrate some of the material and immaterial needs and difficulties of those who "não se deram bem", that is who did not have success abroad, reporting the voices of some operators who offer direct assistance to the returnees, focusing on the NGO Projeto Resgate. In the last part, I explore the case of Sabrina. I indeed believe, along with Dias and Sprandel ${ }^{11}$, that in order to reduce the distance between policies, legislations and network of assistance, which tend to use homogenizing and exogenous categories and apply standard procedures to an irreducible complexity, it is important to bring foreground "the individual experience of concrete subjects"12.

\section{Trafficking Returnees: the "Palermo Protocol" and the Brazilian response}

Similarly to other kinds of migrant and refugee, displaced and diasporic subjects, who come back to their homeland in various ways and for different reasons, the returnees of HT occupy their particular position. The second part of the Protocol to Prevent, Suppress and Punish Trafficking in Persons, Especially Women and Children, supplementing the UN Convention against Transnational Organized Crime (Palermo Protocol), entered into force in 2003, is titled "Protection of victims of trafficking in person" and consists of articles 6, 7 and 8. Paragraph 3 of article 6 states that each State Party should "provide for the physical, psychological and social recovery of victims of trafficking in persons", also in cooperation with NGOs and other entities of civil society, to offer a series of services, such as housing, legal counselling, medical and psychological assistance, employment, education or vocational training. Article 8 concerns the repatriation of victims and suggests that each State Party should facilitate and make the victims' return, which "shall preferably be voluntary", fast and safe.

\footnotetext{
${ }^{10}$ BROTHERTON, David C.; BARRIOS, Luis. Displacement and stigma: The social-psychological crisis of the deportee.

${ }^{11}$ DIAS, Guilherme M.; SPRANDEL, Márcia. A temática do tráfico de pessoas no contexto brasileiro.

12 Ibidem, p. 66.
} 
Brazil ratified the Palermo Protocol in December 2004. In 2006, the National Policy to Counter Trafficking in Persons was created. The first National Plan of Action was approved in 2008, and lasted for two years, and in February 2013 the legislative decree $n^{\circ} 7.901$ approved the second NPA, valid until 2016.

In section 3, article 7, under the Specific Directives of the National Policy, the dispositions regarding assistance also include juridical, social, consular and health protection to "direct and indirect victims", along with social, community and family reintegration and sheltering, with particular attention to the specific needs of the person (such as gender, "social or ethnic origin", and profession). In the third chapter, on implementation and actions, regarding the area of Social Assistance, it is stated that victims should receive an integral assistance inside the Single System of Health and of Social Assistance $^{13}$, whereas regarding the area of Protection and Promotion of Woman Rights, the Reference Centres for Woman Care in a Situation of Violence are indicated as the structures where care services for trafficked women should be fostered.

The first NPA 2008-2010 was elaborated by an Inter-ministerial Working Group in accordance with the Palermo Protocol, the National Policy, treatments and bilateral initiatives inside Mercosul and the Organization of American States (OAS), and other National Plans (such as the one for the Eradication of Slave Work of 2003 and for Women Policies of 2005). In response to the above mentioned Art. 6 of the Palermo Protocol, and limited to the interest of this text, in the second main strategic line of assistance to the victims ${ }^{14}$, fifteen Centres for Facing Trafficking in Persons were created, including the one in Goiás I did research with, 126 new Centres of Specialized Reference of Social Assistance (CREAS) ${ }^{15}$ and six Humanized Assistance

\footnotetext{
${ }^{13}$ The Single System of Social Assistance [Sistema Único de Assistência Social - SUAS] is the Brazilian public system which organizes the socioassistencial services, in a decentralized and participative manner. The System is coordinated by the Ministry of Social Development and Fight to Famine [Ministério do Desenvolvimento Social e Combate à Fome -MDS] and it is divided in two kinds of social protection, one basic and the other special. Among the cases included in the Special Social Protection, they are included the victims of HT (cf. < http://www.mds.gov.br/assistenciasocial/ suas $>$. Accessed: 26/9/13).

${ }^{14}$ It is relevant to notice that for victims eligible of non-discriminatory assistance they are intended not only Brazilian citizens, but also foreign people trafficked to Brazil, since this is considered a country of origin, transit and destination. In addition, the National Immigration Council in December 2010 edited the normative $n^{\circ} 93$ disposing for the concession of permanent visa or residence in Brazil to foreigners considered victims of trafficking in persons (cf. <http://portal. mte.gov.br/data/files/FF8080812D5CA2D3012D60D125BF0640/Resolu\%C3\%A7\%C3\%A3o\%20 Normativa\%20n\%C2\%BA\%2093,\%20de\%2021_12_2010.pdf>. Accessed: 6/11/13).

15 The CREAS, staying for Centros de Referência Especializado de Assistência Social, are the public units offering special and ongoing services for families and individuals in a situation of threaten or
} 
Offices to Migrants at some international border locations and airports, in addition to the capacity building of the Network of Assistance.

In the most recent second NPA, elaborated after a second cycle led by another Inter-ministerial Working Group - of national dialogues, analyses, meetings and conventions among civil society, ministries, organs of the Network to Face Trafficking in Persons and a Parliamentary Enquiry Commission of the Senate, five broad operational lines were established ${ }^{16}$. The area of recovery and reintegration for victims of trafficking and their families, Brazilians and foreigners alike, cuts through the first three lines ${ }^{17}$, but it can be said to be concentrated in the second one titled "Integration and strengthening of public policies, assistance networks, organizations offering services necessary to face trafficking in persons". This line is rather complex and articulated, and does not take radical distance from the previous plan, but rather operates a clear and detailed systematization of means, actions and responsible actors. In general, the actions regarding the NETPs, the Advanced Offices, the Committees for Facing Trafficking in Persons and the Network of Assistance, call for a strengthening of an integrated activation towards an institutionalization of the Centres and the creation, funding and implementation of national systems for an integrated assistance, a common methodology and a constant monitoring. The objectives are, among others, to create a national protocol of treatment, provide funding for the victims who want to come back to their communities, to implement the public services inside the CREAS and the SUAS, to sensitize town halls and local net of assistance and reception, along with the creation of twenty Centres of Special Reference for Woman Attendance, qualified for caring and protecting the victims (activity 2D).

violation of their rights. The main focus of the service should be the family and community relations, and the actual lived experience of the subject (cf. <http://www.mds.gov.br/assistenciasocial/ protecaoespecial/creas $>$. Accessed: 26/9/13).

${ }^{16}$ For a detailed report of the elaboration process of the II NP see the document titled "Relato Processo II PNETP" at the webpage <http://portal.mj.gov.br/main.asp?View $=\{$ E8833249-5827-4772BDC6-D7F1D880AD41 $\} \&$ BrowserType $=$ NN\&LangID $=$ pt-br\&params $=$ itemID\%3D $\{$ B5014675B763-4282-891A-784E0688387A $\} \% 3 B \& U I P a r t U I D=\{2868 B A 3 C-1 C 72-4347-B E 11-A 26 F$ 70F4CB26\}. Accessed 27/9/13. For the final report of the Parliamentary Enquiry Commission on Trafficking in Persons of the Senate (Comissão Parlamentar de Inquérito - CPI) see <http://www. senado.gov.br/atividade/materia/detalhes.asp?tab=t\&p_cod_mate=99441>. Accessed 27/9/13.

17 For example, inside the first line, regarding the improvement of the normative framework, it is stressed the importance to redefine the competences of the NETP, of the Advanced Offices and of the Committees for Facing Trafficking in Persons. For the full text of the II NP see <http://portal. mj.gov.br/main.asp?View $=\{$ E883324958274772BDC6D7F1D880AD41 $\} \&$ BrowserType $=$ NN\&L angID $=$ ptbr\&params $=$ itemID\%3D $\{$ B5014675-B763-4282-891A784E0688387A $\} \% 3 B \& U I P a r t U I$ $\mathrm{D}=\{2868 \mathrm{BA} 3 \mathrm{C}-1 \mathrm{C} 72-4347-\mathrm{BE} 11-\mathrm{A} 26 \mathrm{~F} 70 \mathrm{~F} 4 \mathrm{CB} 26\}>$. Accessed 27/9/13. 
Despite such evident policies' efforts and improvements, it is interesting to notice that, the well-known international analysis TIP $(2013)^{18}$ highlights the inadequacy of funding for specialized assistance and services for victims, like ad hoc shelters, on behalf of the Brazilian government, despite the funding of 16 anti-trafficking offices and 12 assistance posts. It is indeed stated that the Ministry of Social Development provides generalized counselling, medical assistance and sheltering to women through its national network, but NGOs observe lack of preparation and funds and often provide additional missing services. The absence of reports with data and figures regarding women and men assisted and the kinds of services provided is also lamented.

This brief overview regarding the international normative, and how Brazil actively responded to it with a series of decrees, plans, amendments and integrated policies, has the meaning of locating the experience of the social actors during fieldwork in the macro-framework of the international and national level. Even though such levels are necessarily distant from the specific everyday life experience and the petty as well as the sever vicissitudes of the returnees I encountered, nonetheless, in a sort of domino wave flowing from the majestic and flawless buildings of UNODC in Vienna to the small and friendly offices of the Reference Centre for Women in Anápolis, passing through Brasília ministerial geometries, they ultimately get to influence the concrete course of life of the people identified as victims of HT.

In a nation-state as large as Brazil, the level of the internal states of the federation is a fundamental intermediate stage for policy implementation and introducing the case of the state of Goiás bring us progressively closer to the microphysics of the research.

\section{Why the state of Goiás?}

According to the International Organization for Migration (IOM), inside the Assisted Voluntary Return \& Reintegration programme (AVR\&R) in Portugal, Goiás, along with Minas Gerais and São Paulo, is the state where the Brazilians are mostly returning to ${ }^{19}$, this means also trafficking returnees. The reasons why Goiás has established itself as one of the Brazilian states with the highest incidence of trafficking in persons and of returned victims have never been systematically researched. Yet, even in the fragmentary

\footnotetext{
18 The TIP is the Trafficking in Persons annual report done by U.S. Department of State (cf. <http:// www.state.gov/documents/organization/210738.pdf>. Accessed: 21/10/13)

19 Datum taken from the video "Stories of Reintegration in Brazil - IOM 2012" (cf. <http://videos. sapo.pt/D1KOoZbVdvWWQidlrgCQ>. Accessed 28/10/13).
} 
and messy nature of data, statistics, and percentages, such reputation seems to strongly persist. Most probably, an element of reality, given the state's tradition of migration, has merged with an early visibility of the state in terms of HT hotspot. This is also due to two researches, in addition to a higher responsiveness and efficiency of the local authorities. Firstly, inside the 2002 pioneering Brazilian Research on the Trafficking in Women, Children and Adolescents for Commercial Sexual Exploitation ${ }^{20}$, the state of Goiás turns out to be a relevant crossroad in an international flux of trafficking of women, coming from smaller urban centres, such as Anápolis, and, ending up in Spain, Switzerland and Portugal, and also in Italy and the Netherlands, via the airport of Goiânia ${ }^{21}$.

Secondly, Goiás was picked up as one of the four states where the first Diagnosis on Trafficking of Human Beings was conducted from 2000 to 2003, inside the partnership between the Ministry of Justice and the United Nations Office on Drugs and Crime - UNODC ${ }^{22}$. Such choice is explained with the fact that Goiás appeared to be one of the areas "most frequently involved in cases of trafficking" 23 , even for the reason that it is near to the states of the Northern Region, involved in the phenomenon of internal trafficking, and to the Federal District and surroundings, scenarios of severe poverty and social problems ${ }^{24}$.

In both researches, the number of police investigations and judicial trials documented in Goiás, and Goiânia specifically, is the highest. This datum, confirmed also by Mr Daniel Rezende Salgado, Prosecutor of the Republic, does not necessarily imply a higher proportionality in relation to other states. In other terms, it is a datum more related to visibility than incidence. "But do you think trafficking occurs more here or not?" I ask him. He wisely pauses for few seconds and replies "it is a rather difficult question [...], it is a very invisible problem [...] I cannot come and say to you Here, there's more trafficking, what I can say is that here, we've done a job that subtracted the problem from invisibility" 25 .

\footnotetext{
20 The so called PESTRAF, acronym of the Brazilian title: Pesquisa sobre Tráfico de Mulheres, Crianças e Adolescentes para fins de Exploração Comercial (<http://resourcecentre.savethechildren.se/ sites/default/files/documents/7265.pdf $>$. Accessed: 21/10/13).

21 LEAL, Maria Lúcia; LEAL, Maria de Fátima (eds.). Research on Trafficking in Women, Children and Adolescents for Commercial Sexual Exploitation in Brazil - PESTRAF: National Report.

${ }^{22}$ COLARES, Marcos. I Dignóstico Sobre o Tráfico de Seres Humanos - São Paulo, Rio de Janeiro, Goiás e Ceará - Pesquisa em Tráfico de Pessoas / Parte 1.

${ }^{23}$ Such datum is said to be derived from various academic researches, but only the one above mentioned, PESTRAF, is referred to (see note 20).

${ }^{24}$ COLARES, op. cit., p. 17.

${ }^{25}$ Recorded interview, 31/8/12, Goiânia (GO). See also I consider tGONÇALVES, Juliana dos Santos; RÉZIO, Juliana Batista; PIRES, Nathália Justo; Mercadoria Humana. Tráfico de Mulheresem Goiás para Exploração Sexual International, p. 51.
} 
As a result of such judicial visibility and of those two researches, partly funded by the US Agency for International Development (USAID), the UNODC, the International Labour Organization (ILO), Goiás started to be particularly visible and active in facing HT. As the first coordinator of the NETP, Mr Saulo de Castro Bezerra of the District Attorney in Goiânia told $\mathrm{me}^{26}$, in 2003 an office to fight HT was established in the frame of an agreement and a financial support with the UN. This first national experiment turned out to be very "frustrating" due toa lack of commitment, clarity of purposes and structure. "The issue was not treated seriously [...] and then the office was closed "after less than two years. At the end of 2006, with the National Policy extremely fresh, during "the peak of the discussion", the then-Public Prosecutor went to Brasilia to seek for an agreement with the National Secretary of Justice/Ministry of Justice and other organizations keen to cooperate, and, after that, he set up the NETP, which still could not have a very clear idea of its task, since there were no models to follow. It was then that Mr Bezerra was called to coordinate the Centre and tried to give it a totally democratic format, adequate to Goiás, and started to consult with all governmental and non-governmental organizations, from religious to transsexual associations, working with human rights' defence. Mr Bezerra began to explain and list me the countless activities of the Centre and the network of organizations, in the different areas of public policies, protection, prosecution and prevention and how it became a unique case in the country.

Going to the socio-historical hypotheses, there is no agreement of why the state could be an actual hot crossroad of trafficking and, therefore, of returns; the reasons provided by the local officials I encountered varied considerably. When I ask Mr Bezerra why UNODC and the National Secretary of Justice decided to invest to set up the first office to fight HT in Goiás in 2003, in other words, why the state already had a reputation regarding the matter and whether it was fact-based, he replies: "In the Centre, we wanted to find an answer to it, also to remove that stigma [...] because some extremely machist answers say that it is because in Goiás there are the most beautiful women of Brazil". I confirm that I had received that answer from high ranked women as well, he nods declaring that sexist education in the state hits both men and women.

Also Ms Maria Rita Madeiros Fontes, Manager of Special Projects and Internalization of Actions of SEMIRA, tells me (lamenting that there are no scientific enquiries supporting her affirmations):

${ }^{26}$ Recorded interview, 7/8/12, Goiânia (GO). 
our main social problem is essentially linked to this issue of feminine repression [...] here in our state the repression of women is very big, machismo is very big [...]. There exists a myth according to which the Goiana woman is trafficked due to her beauty, her charming physical appearance...in my experience, I think it's the opposite: it's repression that provokes women attempt to get out of this state of repression, of this state of subjection and look for [...] another kind of freedom that she idealizes, but that in reality... it is for this that she is so susceptible to recruitment, to the recruiter, because the recruiter promises things to her that she doesn't have here ${ }^{27}$.

Ms Fontes goes on explaining that this condition of women in Goiás could be explained with the specific history of this part of Brazil, populated by bandeirantes between XVII and XVIII centuries in search of gold and other minerals who rooted a rural agro-business oriented mentality of female obedience to men. She affirms that she is not witnessing much change, but rather a perpetuation of a machist culture, on behalf of women themselves, and "flagrant" lack of opportunities for women.

The relevant scarcity of opportunities for women in Goiás, along with a feminized poverty, is a rather transversal reason for explaining the supposedly higher incidence of HT in the state. Another one, between guessing and evidence, with the basis on some figures given by few European NGOs and an IOM research ${ }^{28}$, is that the majority of Brazilians there are Coianienses. Nonetheless, given the evident strategic central geographical position of the state, which can favour the link between internal and international mobility, it is reasonable to suppose that many women declare to come from Goiás simply because they depart from here, while they have already migrated from other Brazilian states, as Mr Bezerra, among others, noticed ${ }^{29}$.

Nonetheless, the well-known Researches in Trafficking in Persons 1 and 2 (2005/2007) provide some figures regarding the higher incidence of Goianiense migrants. They were conducted inside the international airport of Guarulhos (São Paulo) in the Humanized Assistance Office to Migrants, at that time managed by the NGOs ASBRAD ${ }^{30}$, to detect the presence of

\footnotetext{
27 Recorded interview, 22/8/12, Goiânia (GO).

${ }^{28}$ In the research, the European states involved are Ireland, Belgium and Portugal. REYNTJENS, Pascal (ed.). Assessment of Brazilian Migration Patterns and Assisted Voluntary Return Programme from selected European Member States to Brazil, p. 38-39.

${ }^{29}$ Recorded interview, 7/8/12, Goiânia (GO). Mr Bezerra also added that in the state it is registered a quicker passport emission, but I could not verify this information elsewhere.

30 ASBRAD (Associação Brasileira de Defesa da Mulher da Infância e da Juventude) is the Brazilian Association for the Defence of Women, Infancy and Youth. It is one of the first Brazilian NGOs, active in the frontline for the reception and recovery of returned victims of HT.
} 
returned victims of HT among deported and non-admitted migrants from Europe. In both investigations, in relation to the state of origin, the majority of the interviewees came from Goiás ${ }^{31}$. Similarly, in other two publications based on the same kind of research titled "Systematization of the experience of the Office Functioning"32 and "Facing Trafficking in Persons - Report of the $1^{\text {st }}$ National Plan" ${ }^{33}$ conducted in the same restricted area where ASBRAD operated inside Guarulhos airport, the majority of the returnees as well as the majority of the possible victims of HT came from Goiás.

One last I would like to relate here is the one of the judge Rinaldo Aparecido Barros of the Court of Justice in Goiânia, a very active figure committed to the matter of trafficking in the state since 2009, when he "started to verify that actually the problem was much bigger than it was initially imagined, and that Goiás, for many years, had been leading the national ranking in numbers of victims regarding trafficking in persons for sexual exploitation" ${ }^{34}$. When I ask him regarding the legitimacy of Goiás special position in relation to $\mathrm{HT}$, he replies: "there is an explication which I consider plausible: that Goiás has a culture of migration, since the '70s, [...] it is a tradition, a costume [...] and, I think since the '90s until now, there has been an increase in departures for prostitution". But again, his affirmation cannot be supported by any solid scientific investigations, even if it is certainly reasonable to suppose, as in any migration flux, the creation of networks, routes and chains of mobility.

In the general scarcity of systematized data and haziness concerning the actual entity of HT in the state, the conclusion we can draw, as said at the beginning of the paragraph, is that on a juncture of socio-historical factors, largely unexplored, but that locate women in a position of disadvantage, along with a tradition of migration on which HT has implanted, local authorities and organizations have been particularly active and efficient. The reason why I considered appropriate to indulge a little in outlining a picture of Goiás in relation to HT is because this is the bigger framework from where the women I encountered come and escape from, as well as the one they come back to, concerning both the socio-economic and personal difficulties

\footnotetext{
31 NATIONAL SECRETARY OF JUSTICE. Relatório. Indícios de tráfico de pessoas no universo de deportadas e não admitidas que regressam ao Brasil via o aeroporto de Guarulhos, p. 40; IDEM. Tráfico internacional de pessoas e tráfico de migrantes entre deportados(as) e não admitidos(as) que regressam ao Brasil via o aeroporto internacional de São Paulo, p. 32-33.

32 IDEM. Sistematização da Experiência de Funcionamento do Posto - Posto de Atendimento Humanizado aos Migrantes.

33 IDEM. Enfrentamento ao tráfico de pessoas. Relatório do Plano Nacional, p. 210-216.

34 Recorded interview, 27/8/12, Goiânia (GO).
} 
they still have to face and the support and care they receive by the network of organizations of the NETP.

\section{Não se dar bem}

In August 2009, the ordinance $n^{\circ} 31$ of the National Secretary of Justice ${ }^{35}$ regulated the activities of the NETPs in Art. $2^{\circ}$. In particular, Art. $2^{\circ}$ $\mathrm{IV}^{36}$, regarding victims' treatment, states that each Centre must "articulate, structure, enlarge and consolidate, starting from the existing services, programmes and projects, a national network of reference and treatment for the victims of trafficking in persons". Projeto Resgate $(P R)$ is one of the 71 institutions (including various prefectures of the state) ${ }^{37}$ constituting such network and it is one of the most active dealing with repatriation and the support for reintegration of Brazilians from abroad. For the follow up of the returnees and their integrated and specialized support, $P R$ coordinates with the local Reference Centres for Women, CREAS and other non-governmental organs all over the country devoted to social assistance, as established by the law $^{38}$. In Europe, $P R$ works in partnership with the IOM, Belgium Caritas, the Brazilian Consulate and the Salvation Army, managing, in this way, to bring back a growing number of migrants per year.

Mr Marco Aurélio Sousa is the executive secretary of $P R$, and he himself is the person who often goes to the airport to receive and assist the Brazilians - not all of them are victims of trafficking, but all of them are in great difficulties - who come back through the support of the organization based in Zurich (Switzerland). Interestingly enough, Mr Sousa told me that the organization precisely originated, six years back, from a growing demand of support to return home from behalf of the many Goianas prostitutes working there ${ }^{39}$. Indeed, according to Mr Sousa, the tradition of emigration

${ }_{35}$ Cf. $\quad<$ http://portal.mj.gov.br/main.asp?View $=\{$ A86C8978-B017-4109-BA62-AF25235D1897 $\}>$ (Accessed 4/11/13).

36 This paragraph was emended by the Ordinance $n^{\circ} 41$ of November 2009 with addition of the verb "enlarge" <http://portal.mj.gov.br/main.asp?View $=\{$ A86C8978-B017-4109-BA62AF25235D1897\}> (Accessed 4/11/13).

37 According to the list given to me by the then coordinator of the NETP Ms Nelma Pontes, in May 2012.

38 The executive secretary of $P R$ explained to me that de facto the coordination and the reference system internal to the network for the management of each case function along treks of personal "friendship". In Goiás this informal way of treating returned victims cases function well according to him, because it is quicker.

${ }^{39}$ Recorded interview, 16/5/12, Goiânia (GO). In this respect, it is worth noting that it is well known the existence in the Goiana town of Uruaçu of a neighbourhood called "das espanholas" [of the Spanish women] in reference to the fact that it was built with the remittance of the prostitutes migrated to Spain. 
presumed by Mr Barros, seems to be registering a decline, especially since 2009 economic crisis, when Europe and the US started to facilitate the return of exceeding workforce. Such North-South trend is highlighted in the last World Migration Report of $\mathrm{IOM}^{40}$, where it can be read that in Brazil, 175,766 individuals (65\% of international immigrants) came back home in 2010 - roughly twice the number recorded in the 2000 census, and mainly from US, Japan and Portuga ${ }^{41}$. According to the Assisted Voluntary Return \& Reintegration programme (AVR\&R), Brazil is the eighth among the top 10 countries of origin for AVR\&R, with 1802 cases in 2012 ${ }^{42}$, whereas in 2006 and 2007 the requests received by IOM-Portugal were between 300 and $400^{43}$, confirming a considerable growth. Still, the data we have on returnees and assisted are fragmented, poor and barely inexistent, as also observed by the last TIP44. Yet, $P R$ has its own archive with figures and typologies of returned migrants ${ }^{45}$. Up to 2010, the organization managed 45 cases, among which 17 are cases of trafficking and exploitation. In 2011 only, the cases were 54, including Brazilians repatriated by IOM, of which 17 were cases of trafficking. Up to October 2012, the cases were 26.

Other than bureaucratically caring of the return process from various European countries (such as Switzerland, Belgium, Spain, Italy, Portugal, etc.), $P R$ takes care of the returnees during their social reintegration in Brazil, essentially providing economic support. The main assistance returned victims need regards the setting up of a micro-business (often a fast food restaurant, a shop or a beauty salon), education and vocational training courses, job equipment, expenses for the house (either to finish buying and building it, or for the furniture or the rent), health care and psychological assistance. When the returnees have minor children, they are also included in the aid programme especially in regard to the payment of school monthly taxes ${ }^{46}$. The material resettlement and economic tranquillity of a returnee are certainly crucial aspects of the reintegration process. According to Mr Sousa,

40 See $<$ http://publications.iom.int/bookstore/index.php?main_page $=$ productinfo\&cPath $=37 \&$ pro ducts id=1017>. (Accessed 27/10/13).

${ }^{41}$ LACZKO, Frank; APPAVE, Gervais (eds.). World Migration Report 2013. Migrant Well-Being and Development, p. 79-80.

${ }^{42}$ See the Annual Review 2012 "Migrant Assistance - Assisted Voluntary Return \& Reintegration Counter Trafficking \& Assistance to Vulnerable Migrants", IOM (cf. <http://www.iom.int/files/live/ sites/iom/files/pbn/docs/Migration-Management-annual-review-2012.pdf > . Accessed 28/10/13).

${ }^{43}$ Datum taken from the video "Stories of Reintegration in Brazil - IOM 2012" (cf. <http://videos. sapo.pt/D1KOoZbVdvWWQidlrgCQ>. Accessed 28/10/13).

${ }^{44}$ See above in the text.

${ }^{45}$ I have to thank Mr Sousa for having shared with me $P R$ archive documents.

${ }^{46}$ Given the great variety of the cases, the amount of USD invested for each case varied considerably from a minimum of 500.00 to a maximum of 8000.00 USD (from $P R$ archive reports). 
an employment is absolutely the main necessity of all returnees, "because they want to be productive again, they want stability" and they desperately need money for their family, the bills, the rent, etc.

Nonetheless, a harder challenge concerns the psychological and relational realms. Returning after a long experience of exploitation means dealing with a series of difficulties rotating around the fall of a project. Such project is evidently not only financial, whereas primarily of social and personal identity. Obviously, for the cases of HT, the return accompanied by a self-recognition as victims, imply a stronger crash, since it means coming to terms with a series of lies and dissimulations directed to oneself, to the family and the community. Indeed, it usually takes time to recognize, accept the condition of exploitation and rebel against it, and then communicate and make it public ${ }^{47}$.

The judge Barros, who I have already introduced above, makes clear this point of the personal frustration of a returnee, linked to the self-recognition as a victim, when he tells me: "In most cases, they do not accept themselves as victims because their objectives is to get a better life, therefore the fact that they admit to be victims is to admit a failure", it is an open shameful declaration, in front of the family and the neighbours, of the collapse of the dream of material and personal realization making meaningful the migratory endeavour. "She leaves in search of prosperity, of a better life and she is coming back violated and with no money"48.

Mr Sousa of $P R$ told me that he often goes to the airport to receive the returnees "because I need to create an empathy. He [the migrant] comes back scared, shameful, because he failed in Europe" ${ }^{\prime 4}$. Mr Sousa also explained that sometimes migration occurs because a neighbour or a friend invites to emigrate, and if they have success and the returnee does not, she/ he feels ashamed and "many do not want to come back because they feel ashamed, deceived, ...they feel like a failure [...] because the other one managed and I didn't'". Along with a feeling of shame, there can also be a great sense of incapacity: "if I was unable to make it in Europe, can it be that I can make it here? [...] and this feeling of failure persists up to the point when he stabilizes", Mr Sousa comments. But when can a trafficking returnee be said to be stable?

\footnotetext{
47 This is not the case of Sabrina who immediately realized that she had been deceived and was being exploited (see below in the text).

${ }^{48}$ Recorded interview, 27/8/12, Goiânia (GO).

49 Recorded interview, 16/5/12, Goiânia (GO).
} 
I ask him how the necessities of the victims are monitored and he explains to me that when they arrive in Brazil, they have already gone through a process of evaluation and possibly recovery inside the NGOs in Europe, "a sabbatical period" during which they can think what they want once they are back. According to this first evaluation, $P R$ can also manage the case accordingly and prepare an ad hoc treatment, activating the appropriate persons inside the local governmental net. Therefore, he continues, when they land, their project is defined: surely some of them change it "because the reality here is different", and the "reality" of Sabrina and of other returnees I met was indeed different, as we will see in the next paragraph.

On a psychological level, returning means a rearrangement of the identity, a reconstruction of a moral system of values and a relocation of a sense of self inside a new social milieu and life plan. In Anápolis, I met various times with the psychologist Cíntia Maria Ferreiera Maia of the Reference Centre for Women. Ms Maia worked in direct contact with some returnees, referred to the Centre also by $P R$, and she argues that the trauma suffered by the returnees of trafficking is greater than that of women victims of domestic violence. Indeed, she explains, when they come back they are unable to establish satisfying and positive relationships, sometimes these are even violent, because in a sense they feel guilty and "that they do not deserve happiness ${ }^{\prime 50}$, in addition to the fact that they often have to face an addiction to alcohol and drugs they contracted in Europe. Sometimes, even, when Ms Maia started perceiving they are victims of trafficking, they leave, since they feel ashamed and dirty, because in this Central-West region, she argues, machismo is extremely rooted in the culture.

According to the psychologist of the NETP of Goiás in the Reference Centre for Equality in Goiânia, Elisabeth Fernandes, psychological violence is the most relevant in cases of trafficking, because, in her experience, the depression returnees have to face is severe, also due to the addiction to drugs and alcohol. Mental health is the most affected since the entire sexual and physical integrity of the individual has been humiliated, and, on top of this, it occurs once they are back, the subsequent exposure of the failure and "this failure is also in the body" ${ }^{\prime 51}$.

Another interesting voice on the psychological struggle for recovery of the returnees of trafficking is the one of Maria Luiza Moura Oliveira, member of the Committee of the Latin-American Observatory of Trade and Trafficking

\footnotetext{
50 Recorded interview, 25/7/12, Anápolis (GO).

51 Recorded interview, 26/7/12, Goiânia (GO).
} 
in Persons and professor in psychology at the Catholic University of Goiás. Professor Oliveira believes that the essence of the violence involved in a trafficking experience is the subtraction "from the subject of his/her condition as a subject of his/her autonomy [...]. Subjection is the worst of all". This corresponds, in terms of violation, to the abuse of the rights as a citizen, for there is the subtraction of the political public identity, having to live in anonymity and undocumented. Even after the victim realizes that she has endured a period of an object-like passivity, nevertheless the condition of subjection "has invaded her life [...] and this creates an existential crisis and desperation: how to get out of this" ${ }^{\prime 2}$.

Therefore, Professor Oliveira has no doubt regarding the fact that someone who lives an experience of such a depth, of privation, isolation from one's own world and of loss "of roots in relation to one's own human existence itself" has a very big impact on the subjective condition of the person, leaving sad marks. Nonetheless, she also believes that the subject has, and must have, the resources to get out of the paralysis of that experience, because that occurrence is not the entire life of the subject and "the subject is much bigger than that event" in her/his life. I argue that the process of returning and reintegration ultimately consists in the positive exit out of that paralysing crisis of self-stigmatization as well as social stigmatization ${ }^{53}$. The returnees I encountered were still struggling to acquire a new smooth mobility in their lives.

\section{Returning}

I lived with Sabrina, her two children and Portuguese partner for more than one month, in a suburban neighbourhood surrounded by favelas and social housing ${ }^{54}$ of the town of Anápolis. During that month I witnessed, day by day, her struggle to redeem herself and to reacquire autonomy as a subject in power of her life, constantly facing the economic difficulties as well as the psychological ones.

Sabrina is approximately my age, by now 32, but amongst her memories she can count: the abandonment of her alcoholic father; the sickness of her

\footnotetext{
52 Recorded interview, 14/9/12, Goiânia (GO). Professor Oliveira also works in the Centre of General Psychological Assistance, a free service of treatment for the citizens inside the University.

53 BROTHERTON, BARRIOS, op. cit.,

${ }^{54}$ For respect to Sabrina and her family I keep the exact name of the neighbourhood secret. The term favela, as Sabrina herself explained to me, refers to the presence of narcotraffic, rather than to the stereotypical image of semi-permanent crowded housing. The social housing I am referring to is one of those created under the project Minha Casa Minha Vida [My House My Life], part of the general attention and improvement of the welfare state and social development of Lula's government.
} 
mother; the aggression with a knife of her brother in law with 17 stabs and various years on probation, re-education and hiding; the assassination by firearm of her first great love, a gigolo narcotrafficker of the area; various kinds of humble jobs to make a living; the birth of the first daughter at the age of 17 , followed, after six months, by the separation from the man with whom she continued, with up-and-downs, for 12 years and had a second child; the entrance into prostitution at the age of 17 , the recruitment by a trafficker and the experience as a sex slave in Spain; an unhappy marriage with an old Spanish man; years of difficult living in various European countries to end up in Switzerland in a troubled cohabitation with a Portuguese bricklayer (the same man who is living with her now); addiction to alcohol and cocaine, with four hospitalizations for overdose; depression and severe eating disorders.

I always remember the comment of the young journalist, well dressed and in a perfect make up, recently landed from São Paulo, with her team, to make a TV report on HT for sexual exploitation, eagerly in search for interviewees. After briefly seeing Sabrina to arrange a meeting and a visit to her house, she asks me: "How old is she?", I tell her the age, and she says to me trenchant: "Acabada" 55 . And I realized that, even when reading in my field-notes that I was very worried for the deterioration of her psychophysical conditions, I never thought of Sabrina as a woman with no hope, all the contrary.

Every morning, Sabrina and Pedro wake up at 7 o'clock to go to work in the restaurant that $P R$ helped them to set up along with a loan from the bank. An unemployed girlfriend of Sabrina gives a hand in order to have something to eat, for she separated from her husband and has two kids to feed. They start cooking for lunch, usually in a good mood, with loud music and full of hope for the day, Pedro goes food shopping on a very small bicycle, while the women start setting and laying the tables and so on, until the first client usually shows up, usually by $11 \mathrm{am}$, and they keep on praying for the next client to come until 3 to 4 in the afternoon, if they decide to close for dinner, otherwise they keep on working until 11 pm. By 7 in the morning, Elisa, the eldest daughter of 14 years, is already in school, yet by midday she finishes and she goes to the restaurant as well to help if necessary, watching TV and getting bored. Victor, 12 years old, goes to school only in the afternoon and the first thing he does once up is to turn the TV on, play a videogame or go to the street. They go to church twice a week, a Pentecostal Evangelic

\footnotetext{
55 In English "Uma mulher acabada" would literally be "A finished woman", meaning a woman who is old already, done, with no hope, whose life has destroyed her. I am vague with respect to the TV programme on purpose.
} 
congregation, and during the celebrations, Sabrina cries all her tears, looking for the strength to keep on going and stay away from drugs and prostitution. Every night, Sabrina comes back home in despair because the business is not going well, it is not even self-sufficient, while the debts for buying the food, paying the rent and the bills are growing. She complains about Pedro, on their fights and disagreements on different topics, and, sometimes, she confessed to me that she would like to go back into prostitution, because, in that way, she could pay off all her debts. Sabrina has been eating and vomiting all day long.

Following the first weekend of work in a club, Sabrina came back home with almost one thousand Real ${ }^{56}$ and promised to her mother that, from that moment, it would never happen again that light and water were cut off in the house for not paying the bills. After roughly 13 years, she was asking even from me to lend her some Real to pay for the electricity when we were left in the candle light for two nights.

Sabrina arrived in Europe with her sister and a cousin, because the promises they received by the traffickers were impressive. She was the most suspicious of the three, but she finally went and find herself in a totally isolated brothel, with other 40 imprisoned women, the majority were Brazilians, forced to work up to 12 hours per day and to observe very strict rules, monitored 24 hours, with their passports and approximately $70 \%$ of their income taken, displaced on Saturday night from the brothel to the discotheque and back, as "a herd of pigs" 57 . After one month, she went into another house run by the same couple of pimps, because she started to fight with her sister, but she spent one more night there and she ran away.

One night, in her simple house, Sabrina showed to me all the pictures she had of her European life, including the one of the little country road covered with snow, in the middle of nothing, she walked in search for a taxi, with only 50 Euros in her pocket, the day she escaped. Since then, her life became even more difficult: she kept doing sex work independently, but always under threat, she became slave of cocaine, she got unhappily married for three years with the man who paid her debt with the traffickers, and she left prostitution. She then tried to take her family to Europe, but they were deported. She became depressed, separated and then she became a prostitute and drug abuser again in the Basque Country. She then recovered herself and went to Switzerland where she met Pedro, who was married

\footnotetext{
$\overline{56} 1000$ Reais correspond now to roughly 300 Euros, at that time it was probably far less, but with a higher local purchasing power.

57 Recorded interview, 25/7/12, Anápolis (GO).
} 
at that time, with whom she started to have a strong relationship. Pedro greatly helped her, also in bringing her children to Europe. But, after a while, she again became seriously sick and depressed. Sabrina and Pedro started fighting constantly. After the third aggression, more than nine years later she had left Brazil, Sabrina packed her stuff, took her children and went to the police station to request for deportation.

In May 2011, Sabrina and her two kids landed in the airport of Goiânia. This time she had nothing, not as the previous times when she was returning full of money and everybody was waiting for her at the airport. She had nothing in Brazil, because her mother spent everything she had been sending for years, probably in gambling. "There was a moment when my family and my kids loved me because I was in Europe" she told me, "because I was sustaining the family, you understand, and a moment arrives when it seems that you don't have value, because you are not there[abroad], you don't have money anymore, so you don't have value anymore. It seems that people do not believe that I will overcome, I will succeed, I will win, I will manage" ${ }^{\prime 58}$.

Indeed, when I ask Mr Sousa with respect to the immaterial necessities of a returnee, he affirms that family affection is very important, along with a sense of security, "because a Brazilian is very much family-oriented" 59 . They want to be close to the family and to the child they had left here and to whom they try to become parents again and not only "sponsors" who send money. And at the airport, this time, there was him waiting, ready to help. And Sabrina recalls that moment with great emotion and as a liberation, even if she had empty ends full of challenges to be faced.

With the support of the programme and the new faith she developed inside evangelism, Sabrina is the only sister among the four of them, plus her mother, who is trying to change her life. But her conditions are still extremely precarious. On one side, she refuses a psychotherapeutic treatment, on the other, she appeals to the Reference Centre and $P R$ essentially for money: but sporadic cash does not bring stability, in the same way as economic tranquillity should go with a socio-psychological one. The social environment of extreme poverty and violence, the presence of the highly problematic family members, the business of the restaurant totally counter-productive for a severe eating disorder, the traumas concerning her intimacy, sexuality and relationship with her partner, among other complexities, make it difficult for Sabrina to resettle, in abroad sense.

\footnotetext{
58 See note 57.

59 In Brazilian Portuguese the idiomatic expression is "O Brasileiro é muito família".
} 
I ask Sabrina how she feels now with respect to her life, if she feels she is on the right track and in control of her life. Sabrina answers affirmatively, telling me how she has gained wisdom from her experience and how she has changed. "Which is the thing that mostly changed you, the lesson that altered your identity, your personality?" I continue, and she reaffirms that she has completely changed, both physically and psychologically, underlining that the fact she is not obliged to lay with men any more gives her strength. Indeed, the thing she mostly values in herself is her determination against constant fear to go back into drugs and prostitution, and the fact that, despite she enters in a shop and she has no money to buy the things her children would like - and therefore it would be so easy to go back to the night club - she is resisting. In the same way, she is trying and "asking God" every day to learn how to love and have a happy sexuality, since her physical and psychological intimacy have been seriously spoiled.

The success of the restaurant was among the dreams for the future, Sabrina mentioned to me that day, but as it was predictable by seeing the actual trend of the business day by day, the restaurant had to close and Sabrina is now searching for another employment ${ }^{60}$. As also Ms Nelma Pontes, the coordinator of the NETP at that time, told me, Sabrina needs to solve things inside herself first, her eating disorder, her depression and her withdrawal symptoms and that the restaurant was not the right track. "She needs to change her life and we will create the conditions for her to seek help in this sense ${ }^{\prime 61}$. I do not think these conditions have never been created.

\section{Concluding remarks}

In this article, I've tried to offer a sense of the multivocal arena of perspectives and actions around the issue of recovery and reintegration (the so called "protection" of the victims in the Palermo Protocol) of the returnees of $\mathrm{HT}$, as it emerged from my fieldwork in Brazil. I briefly presented the guidelines of the UNODC Protocol, followed by the main governmental measures and directives regarding the assistance to the returnees. I then offered a concise overview of the state of Goiás as one of the first Brazilian state where the phenomenon of HT started to be particularly present, visible and studied, most probably due to a combination of factors, such as a machist rural culture, a strategic geographical position, a tradition of emigration with the consolidation of some female migration chains, including a good percentage of sex work migration, as well as the presence of poverty, low education and social violence.

\footnotetext{
${ }^{60}$ I could not reach Sabrina recently, but I receive news of her from Mr Sousa.

${ }^{61}$ Unrecorded conversation, 27/8/12, Goiânia (GO).
} 
However, Goiás is also a state where the problem of HT has been readily faced, both in terms of assistance, as the functioning of the NETP demonstrates, and in terms of prosecution, as the number of judicial cases show. I then approached the needs and the problems of the returned victims, reporting the voices of some operators assisting them directly, in order to progressively get closer to a series of more intimate difficulties and psychological marks, other than the economic and material ones, such as the senses of failure, shame and guilt in front of an often stigmatizing community. I finally illustrated the case of Sabrina, aiming at offering an idea of her everyday greatest struggle for recovery and reintegration, in comparison and as a lived response to the governmental and humanitarian discourses and practices, and to lower down into a micro local world the broader phenomenon of migrating and returning after an experience of exploitation. Indeed, as both Abu-Lughod ${ }^{62}$ and Brettell ${ }^{63}$ argue, the objective is to acquire insights on an individual life and agency within broader extra-local political, historical and cultural scenarios, and vice-versa.

In the testimony Sabrina gave during the Regional Seminar on the Fight against Trafficking in Persons in Anápolis, that I reported at the beginning of this text, as well as during the interview she did with me, she depicted the moment of return and her present life as a happy rebirth. Yet, by living with her, the actual local world is far more complex and hard, revealing a strong disorientation and a sort of "reverse culture shock"64. Through the story of Sabrina, I intended to point out both the value of good policies, state measures and humanitarian aid services, governmental and non-governmental organizations, but also the distance between these last ones and the actual conditions of the psychosocial suffering of the subjects, their families and communities. This suggests the necessity of long term ad personam assistance, including the creation of a net of trustful human relations around the subject, for the return is a long and tortuous process of "home making" 65 involving a deep resettlement and transformation of the returnee. Furthermore, it seems clear that policies and assistance aid services should also take into account the familiar and social milieu of the returnees, as well as work in the sense of a progressive eradication of traditions of women discrimination resulting into exploitative migration experience. Otherwise, the risk is that migrants, already coming from a position of marginality, which is also geographical and of

\footnotetext{
62 ABU-LUGHOD, op. cit., p. 150

63 BRETTELL, Caroline. Anthropology and Migration. Essays on Transnationalism, Ethnicity, and Identity, p. 24-26.

${ }^{64}$ GRAHAM, Mark; KHOSRAVI, Shahram. Home is where you make it: repatriation and diaspora culture among Iranians in Sweden, p. 126.

${ }^{65}$ HAMMOND, Laura. Tigrayan Returnees Notions of Home: Five Variations on a Theme.
} 
vulnerability, often also biographical, once back to their homeland, end up into partially new, partially old circuits of marginality and personal abandonment and isolation, rather than reaching, over the years, a full existential stability.

\section{References}

ABU-LUGHOD, Lila. Writing against culture. In FOX, Richard G. (ed.). Recapturing Anthropology: Working in the present. Santa Fe: School of American Research Press, 1991, p. 137-62.

AGUSTíN, Laura María. Forget Victimization: granting agency to migrants. Development, v. 46, n. 3, 2003, p. 30-36.

ANDRIJASEVIC, Rutvica. Beautiful Dead Bodies: Gender, Migration and Representation in Anti-Trafficking Campaigns. Feminist Review, v. 86, 2007, p. 24-44.

BRETTELL, Caroline. Anthropology and Migration. Essays on Transnationalism, Ethnicity, and Identity. Oxford: Altamira Press, 2003.

BROTHERTON, David C.; BARRIOS, Luis. Displacement and stigma: The socialpsychological crisis of the deportee. Crime, Media, Culture, v. 5, n. 1, April 2009, p. 29-55.

CASEY, Edward S. Getting Back Into Place: Toward a Renewed Understanding of the Place-World. Indiana University Press, 1993.

COLARES, Marcos. I Dignóstico Sobre o Tráfico de Seres Humanos - São Paulo, Rio de Janeiro, Goiás e Ceará - Pesquisa em Tráfico de Pessoas / Parte 1. Brasília: Secretaria Nacional de Justiça, 2004 [I Diagnosis on Trafficking of Human Beings - Research in Trafficking in Persons / Part 1].

DIAS, Guilherme M.; SPRANDEL, Márcia. A temática do tráfico de pessoas no contexto brasileiro. REHMU - Rev. Interdiscipl. Mobil. Hum., Brasília, v. XVIII, n. 35, 2010, p. 55-68.

DOEZEMA, Jo. Who Gets to Choose? Coercion, Consent and UN Trafficking Protocol. Gender and Development, v. 10, n. 1, 2002, p. 20-27.

GRAHAM, Mark; KHOSRAVI, Shahram. Home is where you make it: repatriation and diaspora culture among Iranians in Sweden. Journal of Refugee Studies, v. 10, n. 2, 1997, p. 115-133.

GONÇALVES, Juliana dos Santos; RÉZIO, Juliana Batista; PIRES, Nathália Justo; Mercadoria Humana. Tráfico de Mulheres em Goiás para Exploração Sexual International. Unpublished Master final dissertation, PUC - GO, Goiânia (BR), 2013 [Human goods - Women trafficking in Goiás for International Sexual Exploitation].

HAMMOND, Laura. Tigrayan Returnees Notions of Home: Five Variations on a Theme. In STEFANSSON, Anders H.; MARKOWITZ, Fran (eds). Homecomings. Unsettling Paths of Return. Lanham: Lexington Books, 2004, p. 36-53.

INTERNATIONAL ORGANIZATION OF MIGRATION. Stories of Reintegration in Brazil. IOM, 2012, video material, <http://videos.sapo.pt/D1KOoZbVdvWWQidlrgCQ>. 
. Annual Review 2012. Migrant Assistance. Assisted Voluntary Return \& Reintegration. Counter Trafficking \& Assistance to Vulnerable Migrants. At a Glance. Geneva: IOM, 2012.

LACZKO, Frank; APPAVE, Gervais (eds.). World Migration Report 2013. Migrant Well-Being and Development. Geneva: IOM, 2013.

LEAL, Maria Lúcia; LEAL, Maria de Fátima (eds.). Research on Trafficking in Women, Children and Adolescents for Commercial Sexual Exploitation in Brazil - PESTRAF: National Report, Giovanna Boselli and Jonathan Duran (trans.). Brasília: CECRIA, 2003.

MARKOWITZ, Fran. The Home(s) of Homecomings. In STEFANSSON, Anders H.; MARKOWITZ, Fran (eds.). Homecomings. Unsettling Paths of Return. Lanhan: Lexington Books, 2004, p. 21-33.

NATIONAL SECRETARY OF JUSTICE. II Plano nacional de enfrentamento ao tráfico de pessoas. Brasília: Ministry of Justice, 2013 [II National Plan to Face Trafficking in Persons].

. Enfrentamento ao tráfico de pessoas. Relatório do Plano Nacional. Brasília: Ministry of Justice, 2010 [Facing Trafficking in Persons - Report of the National Plan].

. Sistematização da Experiência de Funcionamento do Posto - Posto de Atendimento Humanizado aos Migrantes. Brasília: Ministry of Justice, UNODC, 2009 [Systematization of the experience of the Office Functioning - Humanized Assistance Office to Migrants].

. I Plano nacional de enfrentamento ao tráfico de pessoas. Brasília: Ministry of Justice, UNODC, 2008 [I National Plan to Face Trafficking in Persons].

. Tráfico internacional de pessoas e tráfico de migrantes entre deportados(as) e não admitidos(as) que regressam ao Brasil via o aeroporto internacional de São Paulo / Parte 3. Brasília: Ministry of Justice, OIT, 2007 [International trafficking in persons and migrant smuggling amongst the deported and non-admitted who come back to Brazil via the international airport of São Paulo - Research in Trafficking in Persons / Part 3 ].

. Política nacional de enfrentamento ao tráfico de pessoas (decreto n 5948 , de 26 de outubro de 2006). Brasília: Ministry of Justice, UNODC, 2006 [National policy to counter trafficking in persons].

. Relatório. Indícios de tráfico de pessoas no universo de deportadas e não admitidas que regressam ao Brasil via o aeroporto de Guarulhos - Pesquisa em Tráfico de Pessoas / Parte 2. Brasília: Ministry of Justice, UNODC, 2005. [Report. Indicia of trafficking in persons in the realm of deported and non-admitted women who come back to Brazil via the Guarulhos airport - Research in Trafficking in Persons / Part 2 ].

O'CONNEL, Davidson J. New Slavery, Old binaries: human trafficking and the borders of "freedom". Global Networks, v. 10, n. 2, 2010, p. 244-261. 
REYNTJENS, Pascal (ed.). Assessment of Brazilian Migration Patterns and Assisted Voluntary Return Programme from selected European Member States to Brazil Research Report September 2007 - February 2009. Brussels (Belgium): IOM, 2009.

UNODC. Protocol to Prevent, Suppress and Punish Trafficking in Persons, Especially Women and Children, supplementing the UN Convention against Transnational Organized Crime. Palermo (Italy), 2009.

U.S. Department of State. Trafficking in Persons Report - TIP, 2013.

\section{Resumo}

\section{Das políticas à experiência vivida e vice-versa: o esforço para a reintegração dos retornados do tráfico humano no Estado de Goiás (Centro-oeste do Brasil)}

Esse artigo ébaseado em uma pesquisa de campo conduzida principalmente no estado brasileiro de Goiás, com o foco nos retornados do tráfico humano (TH). O texto tem forma de funil: das políticas internacionais e nacionais, à relevância do estado de Goiás como uma área essencial para investigar tanto os fenômenos como as medidas para contê-lo, às vozes de alguns operadores governamentais e não governamentais que assistem diretamente e se importam com as necessidades das ex-vítimas, até o dia-a-dia da vida mais íntima de um caso emblemático de um ator social. O objetivo é deixar emergir as complexidades dos pontos de vista sobre o assunto da reintegração dos retornados do TH. O retorno é entendido não apenas como um mero deslocamento geográfico, como uma simples volta para a casa ou como uma questão de boas políticas e programas de proteção. Também é abordado como um profundo, longo e tortuoso reassentamento das subjetividades que o empreendem. De fato, por meio da história de Sabrina, eu pretendo assinalar o valor das boas práticas, das medidas estatais, dos serviços assistenciais humanitários, mas também da distância entre estes e as atuais condições do sofrimento sócio-psicológico dos migrantes retornados, suas famílias e comunidades.

Palavras-chave: tráfico humano (retornados), migração de retorno, reintegração, serviços assistenciais, políticas, Goiás (Brasil).

Received for publication in Agosto, 27 $7^{\text {th }}, 2013$. Accepted for publication in November, 12 ${ }^{\text {th }}, 2013$.

Recebido para publicação em 27/08/2013.

Aceito para publicação em 12/11/2013.

ISSN impresso: 1980-8585

ISSN eletrônico: 2237-9843 